\title{
Consolidating Capitalism
}

By Jeffrey Sachs

The 1990s is one of the great watershed decades in economic history. The postwar division of the world economy into the First, Second, and Third Worlds has ended. Not only has communism collapsed, but other ideologies of state-led development that were prevalent in the Third Word for decades have fallen into disrepute. If the United States and the other industrial democracies act with wisdom, they have a chance to consolidate a global capitalist world system, with profound benefits for both the rich and the poor countries. But the greatest foreign policy misjudgment of our time would be to assume that such a system will automatically fall into place. Weak U.S. leadership and fractious relations among the industrial democracies are already putting at risk the unprecedented opportunity to create a law-bound and prosperous international system.

The overarching benefits of the emerging world capitalist system, if it takes hold, will lie as much in global security as in economics. With a few notable exceptions, the market revolution has gone hand in hand with a democratic revolution. That is true in virtually all of Latin America, Central Europe, and the former Soviet Union, and also in parts of East Asia (South Korea and Taiwan) and Africa. The spread of democracy by itself almost surely reduces the risks of war, as do the increased economic links among countries. Careful scholarly work has bolstered rather than weakened the old claim that democracies do not wage war on each other, as Yale political scientist Bruce Russett has recently demonstrated in Grasping the Democratic Peace. It has been instructive, and no accident, that Russia's elected Duma has become the most ardent voice for peaceful rather than military solutions to the deepening conflicts among Russia's diverse regions.

While globalization may seem to be a well-worn theme, it remains poorly understood, which to account for the weak international leadership at the moment. Moreover, policies to promote global integration, such as the new General Agreement on Tariffs and Trade (GATT) accord, are becoming highly contentious in the advanced economies. The halfcentury commitment of the United States to open international trade is under unprecedented attack from various ideologies on the Left and Right. Free trade is even more strongly under attack in parts of Europe, such as France. And key tools to promote the new international system, such as foreign aid, are similarly under unprecedented attack.

This essay aims to put the recent globalization in historical context and to identify the policies needed to consolidate a new international economic system. The world has much to gain from the emerging system, and much to lose if we fail to act decisively to put it in place.

As a result of developments of the past decade, a global capitalist economy is within view for the first time, though it has not yet arrived. Countries with a combined population of roughly 3.5 billion people have undertaken radical economic reforms to adopt the institutions of the capitalist system. These core reforms include six common points: (1) 
open international trade; (2) currency convertibility; (3) private ownership as the main engine of economic growth; (4) corporate ownership as the dominant organizational form for large enterprises; (5) openness to foreign investment; and (6) membership in key international economic institutions, including the International Monetary Fund (IMF), the World Bank, and the GATT, which is now superseded by the new World Trade Organization (WTO). The revolution is remarkable in two dimensions: the "extensive" margin (the worldwide scope of the policy changes), and the "intensive" margin (the depth and complexity of the new economic links among countries).

While specific forms of advanced capitalism in the United States, Western Europe, and East Asia certainly differ, they all share the six basic characteristics just enumerated. There are two main dimensions of difference among the alternative "models" of capitalism: the extent of the social welfare state and the nature of corporate ownership. On the first, Western Europe has by far the most extensive social welfare system in the capitalist world, followed by the United States, and then East Asia With regard to corporate governance, Western Europe and Japan have more extensive cross-holdings of equity ownership by non-financial corporations (that is, enterprises holding shares in each other), and more bank ownership of enterprises, while the U.S. and British economies have traditionally relied more heavily on public ownership via traded shares in stock exchanges. There are of course also differences in the role of industrial policy, state ownership, and openness of the economies, but those differences tend to be exaggerated by some analysts. Note that even the most market-oriented economies are not strictly laissez-faire. Capable public administration is surely needed to guide infrastructure, enforce laws, protect the environment, and promote public health and education.

Much is written about the relative merits of the alternative models, but in terms of globalization, the overriding similarities of the advanced capitalist economies are more important than the differences. For a developing country rejoining the world system, the fact that the advanced economies all share certain key features--openness, private ownership, corporate governance--offers a relatively straightforward set of guideposts for the most fundamental reforms. Moreover, increasing internationalization of the advanced economies seems to be eroding the structural differences among them. The welfare state in Western Europe is likely to be trimmed in coming years, while stock market ownership seems to be gaining importance relative to corporate cross-holdings in Europe and Japan

It is important to remember that as recently as the late 1970s, only around one-fourth of the globe--the First World--operated according to the core capitalist institutions. The socialist world included around 26 countries, with a combined population in 1986 of 1.7 billion people, or 34 per cent of the world system The dozens of non-socialist developing countries were mainly pursuing models of "state-led industrialization," in which the state aimed to lead the industrialization process through state ownership of industry and extensive trade restrictions to protect so-called infant industries (which all too often were already senescent industries). In fact, only a handful of developing countries, mainly in East Asia, adopted institutions that were recognizably "capitalist" in orientation. 
Those that did were a lucky few. If there is one overriding lesson from the comparative growth experience of the past 50 years, it is that capitalism "pays." If we consider countries that maintained the main precepts of capitalism--open trade, currency convertibility, and the private sector as the engine of growth--throughout the 1970s and 1980 s, there is apparently not a single development failure among them. All countries that played by the rules throughout this entire 20-year span experienced increases in per capita income, with the poorer countries tending to grow more rapidly than the richer ones, and therefore tending to "converge" in living standards. Of course, the outwardoriented economies of East Asia (Hong Kong, Singapore, Taiwan, and South Korea) are the prime exemplars, but there are success stories as well among the poorer countries in all regions of the world. Many countries that behaved badly until recently and have only now adopted the core capitalist institutions are stuck in a transition crisis.

\section{TRIUMPH OF CAPITALISM}

If capitalist economic performance has been so dominating, how can we account for the fact that the vast majority of developing countries chose anticapitalist policies until recently, policies that left them in poverty and often in financial bankruptcy? Answering that crucial question will help us to understand the risks that still face in consolidating the emerging international system.

The sharp divisions of the capitalist and non-capitalist: world date back around 150 years, to the $1840 \mathrm{~s}$. Before the nineteenth century, there was, of course, no modem capitalist economy anywhere. While many aspects of modern capitalism predate the nineteenth century (especially the mechanisms of international trade, contract law, commercial banking, and even rudimentary capital markets), the modern capitalist system really emerged at the start of that century, with the development of the factory system, the modern corporate form for company organization, central banking, the final elimination of service obligations in Western Europe, and the easing or elimination of mercantilist trade practices. These characteristics of the modern capitalist world emerged first in England and its colonies, and then spread to Western Europe (some carried by Napoleon's armies, others by imitation in the face of the evident superiority of English or French examples).

By the 1840s, the profound economic superiority of capitalist institutions was apparent to keen observers no less than Karl Marx and Friedrich Engels, who rightly predicted in The Communist Manifesto that capitalism would undermine traditional societies:

The bourgeoisie, by the rapid improvement of all instruments of production, by the immensely facilitated means of communication, draws all, even the most barbarian, nations into civilisation. The cheap prices of its commodities are the heavy artillery with which it batters down all Chinese walls, with which it forces the barbarians' intensely obstinate hatred of foreigners to capitulate. It compels all nations, on pain of extinction, to adopt the bourgeois mode of production; it compels them to introduce what it calls civilisation in their midst, i.e., to become bourgeois themselves. In one word, it creates a world after its own image. 
This proposition was put to the test from the 1840s onward, and has been nearly vindicated, but on after 150 years of wrenching confrontations between capitalism and traditional societies. The puzzle is not that capitalism triumphed, but that it took so long China was the first to feel the onslaught, in the Opium War of 1839-42, which gave the British a foothold on the Chinese mainland. Russia was confronted with the stark evidence of its relative industrial backwardness in its stunning loss to Great Britain in the Crimean War of 1854-56. Japan was shocked out of complacent isolation by the arrival of Commodore Matthew Perry's Black Ships in Edo Bay in 1853. India was finally swallowed whole by the British in 1858, after more than a century of encroaching control by the British East India Company. The Ottoman empire was dismantled piece by piece, beginning with the British occupation of Aden (1839) and the French conquest of Algeria (completed in 1847).

The traditional empires (excepting colonized India) attempted at least some partial modernizing reforms in the face of the Western onslaught. For example, in Russia, the 1860s were an era of significant reforms under Alexander II, with the emancipation of the serfs (1861), the introduction of an independent judiciary (1864), and the start of local self-government (1864). But by the 1870s, these partial reforms had stalled, and with Czar Alexander's assassination in 1881, a wave of reaction followed. Further reforms under Count Sergei Witte (1890s) and Prime Minister Pyotr Stolypin (1900s) left Russia financially fragile and therefore prone to collapse in World War I. The Bolshevik Revolution, far from inevitable, filled the vacuum of the financial chaos of 1917.

In China, reforms were delayed until the first decade of this century, after China's imperial rulers were stunned by their loss in the war with Japan in 1895. As in Russia, when the Ching dynasty eventually collapsed in 1911, the financial rot was so far advanced that it proved impossible to consolidate a new, modernizing regime. China fell prey to warlordism and then to the Japanese invasion of 1931.

Only Japan met the capitalist challenge by a systematic adoption of Western institutions, in what became history's first case of "shock therapy" economic reforms. Between 1868, the start of the Meiji Restoration, and 1885, the new Japanese leadership systematically put in place the new capitalist institutions copied from the West. Japan eliminated feudal institutions, introduced taxation in money rather than in kind, initiated a private market in land, created a stable currency, opened the economy to international trade (under the strictures of the "unequal treaties" imposed by the Western powers), introduced commercial law (much of it copied from German commercial law), reorganized the government on cabinet lines, and so on. Those reforms ushered in a century of remarkable economic growth that carried Japan to the number two position in the world economy.

Japan remained the only significant non-European power to make the transition to modern capitalism until after World War II. If we examine the fitful process of reforms in Russia, China, the Ottoman Empire, and elsewhere, we note that those countries too might have eventually made a successful transition--more gradually and less boldly than in Japan--were it not for the upheavals of World War I, the consequent financial turmoil 
of the 1920s, and the collapse of the international economy in the Great Depression of the 1930s. By the time World War II ended in 1945, there was no international trading system; no convertible currencies except the American dollar; and no moral attraction in the developing world to a capitalist system that had led to imperialist plunder, depression, and two world wars in 30 years.

After 1945, the world divided into the proverbial First, Second, and Third Worlds, and the division remained mostly intact until the 1980s. The First World was reconstructed under U.S. auspices, starting with the Bretton Woods institutions, the GATT, the Marshall Plan, and the European Economic Community. A few developing countries, particularly in East Asia (South Korea and Taiwan), joined the system, mostly to reinforce their place under the U.S. security umbrella The Stalinist model was imposed in the Second World, including on the formerly capitalist economies of Czechoslovakia, Hungary, and Poland.

The nationalist leaders of the newly independent states of the Third World, such as Jawaharlal Nehru, Sukarno, and Kwame Nkrumah, made a thoroughly understandable, if deeply flawed, economic choice in the late 1940s to try to protect their hard-won independence through autarkic policies and forced industrialization promoted by the state. After all, independence had been won on the Gandhian rallying cry of "selfsufficiency." Moreover, few economists in the leading countries demurred at these choices. Following John Maynard Keynes, the capitalist world was "known" to be unstable (witness the Great Depression). The state became the great stabilizer. In any event, there was barely a "world economy" to join, following the disasters of the Great Depression and World War II.

\section{REVOLUTION IN THE 1990S}

The Capitalist Revolution of the 1990s is the unraveling of the tripartite world system that emerged after World War II. There is, of course, one overriding reason for the revolution: The alternatives proffered by the Second and Third worlds did not work. At the same time, the countries that joined the First World experienced an economic boom of unprecedented magnitude, and they included the handful of poor countries in the world that happened to land on the right mixture of economic policies.

It is interesting to note that the collapse of the Second and Third World models of stateled, autarkic development proceeded according to a common pattern. There were, in most cases, three steps on the way to collapse. The first stage of the state-led strategy actually worked reasonably well in most of the countries. It turned out that certain kinds of heavy industry--such as steel mills and coal mines--were enough like bureaucratic units, with standardized inputs, outputs, and technology, that they could be run effectively as state enterprises. It is these heavy industrial sectors that were the first, and generally only, successes of state-led industrialization. State-led industrialization was also particularly effective when poorer countries could draw on reserves of low-productivity agricultural workers for low-wage employment in the new factories. 
The second stage was the onset of economic stagnation, already beginning in the early 1960s. While state-led industrialization could spur heavy industry, it could not succeed in the next stage of spurring consumer goods industries, services, or product and process innovation. Also, large reserves of low-skilled agricultural labor diminished as industrialization and urbanization proceeded. Countries found themselves saddled with hothouse industries, protected by tariff and quota barriers, and kept alive by subsidies, but with little use of their outputs. In Latin America, this became known as the crisis of "the second-stage of import substitution." It was universally agreed that the second-stage of import substitution was much more difficult than the first. Yet there were still relatively few calls to abandon the strategy altogether.

In the socialist countries, the problems of stagnation were also becoming evident in the early 1960s, prompting Nikita Khrushchev to authorize the experimentation with market incentives under the so-called Liberman reforms, which were aborted when Khrushchev fell from power. In Poland, economic stagnation led to the ouster of one party secretary and his replacement by another who promised to speed economic growth by importing modern technologies from abroad The regime embarked on a borrowing spree that raised the country's foreign debt to more than $\$ 42$ billion in 1987 , which equaled 70 per cent of the country's gross national product The only significant result of that borrowing spree was to drive the Polish government into bankruptcy at the end of the 1970s

The pattern of stagnation leading to foreign borrowing was re-played dozens of times throughout the socialist and developing countries. Foreign borrowing, in short, became the illusory way to "fix"

more fundamental problem of economic policy. It failed to work, of course, leaving much of the Second and Third Worlds in financial distress by the 1980s. Virtually every Latin American government was in default on foreign bans by 1983; Hungary and Yugoslavia fell into acute financial crises by the mid-1980s, and Bulgaria defaulted on its foreign debts at the end of the 1980s. Of course, external shocks (such as swings in oil prices and spikes in word interest rates in the early 1980s) sometimes played a role in the onset of state bankruptcy, but it is clear that poor policies rather than external shocks were really decisive. Strikingly, Mexico, Nigeria, and other profligate oil exporters went bankrupt in the early 1980s in the midst of an unprecedented oil export boom, as a result of incredible government waste, inefficiency, and corruption attendant upon a state-led strategy for industrial development.

Remarkably, Mikhail Gorbachev replayed the foreign debt disaster 15 years after Poland's debacle by the decision to jump-start the Soviet economy through foreignfinanced modernization in the second half of the 1980s. The Soviet Union's foreign indebtedness grew from $\$ 28$ billion in 1985 to $\$ 67$ billion in 1991 . With no increased export capacity in sight, the creditors finally puled the pug, ceasing new lending and demanding a repayment on earlier credits. The Soviet government went into default in late 1991, just as the Soviet Union itself collapsed.

\section{RISKS TO THE SYSTEM}


The most remarkable story of the past 50 years is not that successful economic institutions inexorably replace unsuccessful ones, but that unsuccessful ones can persist so long, often at the cost of unimaginable human suffering. Russia and China delayed reforms in the nineteenth century until their teetering empires suffered utter fiscal and military collapse. Other countries finally succumbed to foreign conquest. Economic weakness, especially in the face of foreign challenges, has often led to extreme militarism rather than economic reform. Retrograde economic institutions can even be imposed on successful countries through military conquest, as with the Soviet destruction of Central Europe's more prosperous economies after World War II.

There are only a handful of countries in the word today that are aggressively shunning participation in the emerging global economy Even Cuba, North Korea, and Iran are trying, if unconvincingly, to court foreign investors. Nonetheless, Russia and China remain with one foot rather tentatively in the global economy, and both face monumental problems of coordinating their opening to the world. At the same time, much of Africa is collapsing from social and economic disorder before sic reforms can be put: into place

The most important strategy problems of international economic policymaking in the next few years win involve the consolidation of market reforms in Russia, China, and Africa. Beyond that, there is the need to avoid backsliding on international commitments made by the developed countries, which are themselves experiencing intense domestic protectionist pressures. Finally, there is the need to deepen the international system of law to better govern the emerging global economy.

Without doubt, the Western neglect of the current Russian economic crisis is the greatest foreign policy failing in decades. Since 1991, Russia has been within reach of successful market reform. Yet, delay in successful economic stabilization in Russia has deeply undermined public support for reforms and added great strength to extremist and military forces within the Russian body politic. The main reformers are now gone from the government, having been defeated at the polls. Not only the Russian economy, but also Russian democracy, has been put recklessly at risk by Western neglect.

The Western effort has failed at three levels. First, there was no intellectual understanding among Western leaders of what to do. The Marshall Plan architects had one brilliant insight that is missing today: The purpose of economic assistance is political, to support fragile democratic regimes attempting to implement more basic reforms. As George Marshall put it in his famous 1947 speech, the aim of aid is to stabilize economic conditions "so as to permit the emergence of political and social conditions in which free institutions can exist." In recent years, by contrast, the little aid that has been provided has been apportioned almost entirely by economic bureaucrats, whose main concern has been the avoidance of "waste," rather than the fate of Russian democracy. Second, the sums have been derisory. In fiscal year 1995, Russia will receive roughly $\$ 380$ million in U.S. aid, or about one-sixth of the aid to Egypt. U.S. aid to Russia will amount to toughly .005 per cent of U.S. gross domestic product (GDP), compared with Marshall Plan commitments to Europe in fiscal year 1949 of 2 per cent of GDP. Russia may or may not 
receive a few billion dollars of IMF support, years later than the money should have arrived from that institution.

Third, the Bush and Clinton administrations failed almost entirely in leading a coordinated Western effort to aid Russia. Virtually all Western "aid" has come in the form of export credits to Russian enterprises, with short periods for repayment, rather than in the form of grants and long-term loans to the Russian budget (almost all of the Marshall Plan support was in the form of grants). Repayments of these loans are already straining the Russian budget. Overall support from Western governments for the Russian budget, vitally needed for stabilization, has been essentially nil. Moreover, despite several hasty announcements of Group of Seven aid packages ( \$24 billion announced in 1992, and \$28 billion announced in 1993), very little coordination was ever undertaken to bring those packages to fruition. In 1994, there was essentially a complete collapse in U.S. attempts to mobilize international assistance from governments on behalf of Russian reform. Now, the IMF and the World Bank are the only real games in town, and they have proved to be hugely insufficient.

The case for foreign aid is the strongest in decades, but the public support is surely at its lowest ebb since the war. Though a democratizing Africa will desperately need support, the new Republican leaders in the Congress have discussed zeroing out Africa in the fiscal year 1996 budget. That position comes from a complete misunderstanding of the role of aid. Yes, free-market Republican critics of aid are correct that foreign assistance cannot substitute for market reforms in producing economic prosperity. On the other hand, they fail to recognize that fragile regimes are likely to collapse before they can implement needed market reforms if aid is not present as a temporary support.

A new public consensus on aid is vitally needed for Russia, Africa, and other reforming countries. In accordance with economic logic and U.S. long-term strategic goals, economic assistance should be guided by the following principles. First, it should go only to countries pursuing market reforms. Second, it should go on to democracies or countries in the process of democratization. Third, it should be limited in time to no more than five consecutive years for a particular recipient, since the goal is to bolster fragile governments, not to finance economic development. Four, it should be mobilized as part of a combined effort of Western democracies, base on agreement on underlying principles.

Would temporary aid really be sufficient? There will of course be individual cases of backsliding even after five years of aid and reform, but the postwar experience suggests that most countries at make it through the treacherous first several years of reform arrive on the other side with positive economic growth and are unlikely to reverse course fundamentally in the future. Of course, economies may stumble--with recessions or new outbreaks of inflation--but governments that have navigated a liberalization of the economy and then held it for several years very rarely adopt high protectionist or statist strategies once again. New social forces, especially newly arisen exporters and the strengthened private sector, add important countervailing pressures. Admittedly, some 
cases where serious reversals occur may merit throwing in another aid lifeline, if a new reformist government takes power at a later date.

For China, Russia, the other successor states of the former Soviet Union, and several countries in Africa, accession to the new WTO win be a crucial step toward joining the word system. The United States right resisted allowing China to enter the WTO during 1994 without further Chinese reforms. The American goal is to induce countries to join a system, not merely a club. And yet, the organizational work to bring in China and these other countries has been inadequate. For most of the former Soviet Union, active negotiations are not yet even underway on accession. The Russian negotiations have been desultory, and are more than a year behind schedule. As with financial aid, delays not only hinder Russian economic recovery, but also put the entire reform at risk by giving time for militarists and extremists to undermine the reforms.

The second enormous risk to the emerging system lies in the developed economies. At the moment of fruition of 50 years of steadfast foreign policy support for an open and law-bound international economic system, international trade is under unprecedented attack. There is little doubt that the increased trade and financial flows between developed and developing countries have created losers as well as winners in the advanced economies. The key is to recognize that the winners vastly outnumber the losers. In the United States, for example, perhaps one-fourth of manufacturing jobs in the most labor-intensive sectors--such as apparel, footwear, and leather goods--have been lost to low-wage competition from abroad; yet manufacturing as a whole accounts for only 17 per cent of total employment, and the workers exposed to low-wage competition are perhaps one-fourth of all manufacturing workers. For that basic reason, a free-trade coalition (of suburban service-sector workers and high-tech manufacturing exporters) has continued to muster majorities against an increasingly strident protectionist bloc. Of course, the economy will continue to be hit by technological shocks as well. as trade shocks. The technological shocks are also very important in provoking shifts in income distribution and patterns of employment, even if such shocks are often harder to identify or quantify.

There is a political and economic case for meliorative measures in response to intensified trade pressures, including further adjustment assistance, enhanced job training programs, and a shift of tax burdens from low-wage labor to other sources of income. And yet, we should be realistic that these measures by themselves will not accomplish all that much. Market inducements will play a much larger role in redirecting job training, shifting patterns of employment across industries and regions, and changing decisions about schooling. In the United States, such adjustments occur relatively rapidly, over the course of five to ten years, not over generations.

The much greater protectionist risks will come from Western Europe rather than the United States. The European Union (EU) labors under a much more extensive, rigid, and expensive social-welfare system than the United States. EU social welfare provisions have slowed the adjustment to low-wage competition, meaning that Europe still has considerably more downsizing ahead than does the United States. Moreover, high levels 
of European taxation continue to chase European capital abroad or into the grey economy, pushing up official unemployment rates to mote than 11 per cent for the EU as a whole. Dangerously, the unease in Western Europe has undermined political support: for quick absorbing Eastern Europe into the EU, with the inadvertent result of undermining Eastern Europe's highly charged and complex economic transition to the market.

The cement that will ultimately hold the world system together is not markets per se, but the international rule of law. The world has already had one brief episode of global market integration at the end of the nineteenth century, under the domination of Western powers, but it collapsed in an orgy of imperialism, lawlessness, and, eventually, war among the leading states of Europe. The weaker countries are now signing on to the world system and joining the global institutions, not only because they recognize the advantages of capitalism, but because they see the hope of joining a system that protects their national sovereignty while operating on the basis of an agreed upon international rule of law.

The public's recognition of and support for international law are both shallow and subject to populistic manipulation. In last year's congressional debate over a new GATT treaty, the leading charge against it was that the international rules of the WTO, especially its new binding dispute settlement process, would deprive the United States of sovereignty. It was essentially the assertion chat the "freedom" of international lawlessness would serve U.S. interests better than the binding constraints of mutually negotiated international law. It is the same sentiment that fuels the U.S. reliance on "tough" unilateral actions against Japan, rather than the reliance on an international system of trade rules These views remarkably fly in the face of the deepest wisdom of the U.S. system, which is based not on liberty alone, but on "ordered liberty" under the constraints of law.

However fragile are American commitments to the international law, they are more fragile almost everywhere else. If the United States undermines its greatest gift to the world community, the commitment to constitutional government, by circumventing rules and looking for short-term trade advantages over its competitors, Americans will find themselves quickly descending into a swamp of mercantilism and trade conflict as other countries abandon the agreements of the international trading system. On the other hand, if the United States can manage to stick with its abiding principles that have brought it to the brink of an integrated, law-bound world system, and if Americans in conjunction with the other advanced democracies can deliver aid with generosity and farsighted selfinterest, this generation has the possibility to usher in an unprecedented period of peace and prosperity. 